Vol. 1 No. 4 Oktober 2021 e-ISSN : 2774-6283 | p-ISSN : 2775-0019

\title{
MENINGKATKAN KEMAMPUAN PENALARAN MATEMATIS SISWA MELALUI PEMBELAJARAN BERBASIS MASALAH MATERI PELUANG KELAS XI TKRO-A SMKN 4 JAKARTA
}

\author{
SOPWATILLAH \\ SMKN 4 Jakarta \\ e-mail: sofwatiella@gmail.com
}

\begin{abstract}
ABSTRAK
Penelitian ini bertujuan untuk meningkatkan kemampuan penalaran matematis siswa melalui penerapan pembelajaran berbasis masalah di kelas XI TKRO-A SMK Negeri 4 Jakarta yang melibatkan 6 siswa. Penelitian ini adalah penelitian tindakan kelas (classroom action research) yang dilaksanakan dalam tiga siklus dan tiap siklus terdiri dari empat tahapan, yaitu perencanaan, pelaksanaan, observasi, dan refleksi. Siswa diberikan tes pada setiap akhir siklus untuk mengukur kemampuan penalaran matematis. Hasil penelitian menunjukkan bahwa pembelajaran matematika melalui penerapan pembelajaran berbasis masalah dapat meningkatkan kemampuan penalaran matematis dari pra penelitian sebesar 39,34 siklus I sebesar 67,65 siklus II sebesar 72,24 menjadi 74,08 pada siklus III. Kesimpulan penelitian ini adalah bahwa penerapan pembelajaran berbasis masalah dapat meningkatan kemampuan penalaran matematis siswa. Peningkatan kemampuan penalaran matematis meliputi aspek: kemampuan memperkirakan jawaban dan proses solusi, menggunakan pola dan hubungan untuk menganalisis situasi matematika, menarik kesimpulan logis dari pernyataan, dan memberikan penjelasan dengan menggunakan model, fakta dan hubungan dalam menyelesaikan soal. Jumlah siswa yang nilai penalaran matematisnya mencapai atau melebihi 75 juga mengalami peningkatan. Pada penelitian pendahuluan belum terdapat siswa yang nilai tes penalaran matematisnya mencapai atau melebihi 75 , sedangkan pada siklus I sebanyak $41,18 \%$ siswa, pada siklus II meningkat menjadi $61,77 \%$ siswa, dan pada siklus III meningkat menjadi 82,35\% siswa.
\end{abstract}

Kata kunci: Penalaran Matematis, Pembelajaran Berbasis Masalah.

\section{ABSTRACT}

This study aims to improve students' mathematical reasoning skills through the application of problem-based learning in class XI TKRO-A SMK Negeri 4 Jakarta which involves 6 students. This research is classroom action research which is carried out in three cycles and each cycle consists of four stages, namely planning, implementation, observation, and reflection. Students are given a test at the end of each cycle to measure their mathematical reasoning ability. The results showed that learning mathematics through the application of problem-based learning can improve mathematical reasoning abilities from pre-study of 39.34 in the first cycle of 67.65 in the second cycle of 72.24 to 74.08 in the third cycle. The conclusion of this study is that the application of problem-based learning can improve students' mathematical reasoning abilities. Improved mathematical reasoning abilities include aspects: the ability to predict answers and solution processes, use patterns and relationships to analyze mathematical situations, draw logical conclusions from statements, and provide explanations using models, facts and relationships in solving problems. The number of students whose mathematical reasoning scores reached or exceeded 75 also increased. In the preliminary study, there were no students whose mathematical reasoning test scores reached or exceeded 75 , while in the first cycle as many as $41.18 \%$ students, in the second cycle increased to $61.77 \%$ students, and in the third cycle increased to $82.35 \%$ students.

Keywords: Mathematical Reasoning, Problem Based Learning. 


\section{Vol. 1 No. 4 Oktober 2021 e-ISSN : 2774-6283 | p-ISSN : 2775-0019}

\section{PENDAHULUAN}

Mata pelajaran matematika bertujuan agar peserta didik memiliki kemampuan sebagaimana tertulis dalam Permendiknas Nomor 22 Tahun 2006 tentang Standar Isi, yaitu: (1) Memahami konsep matematika; (2) Menggunakan penalaran; (3) Memecahkan masalah; (4) Mengkomunikasikan gagasan; (5) Memiliki sikap menghargai kegunaan matematika dalam kehidupan. Berdasarkan tujuan pelajaran matematika tersebut, aspek penalaran merupakan kemampuan yang harus dimiliki siswa sebagai standar yang harus dikembangkan.

Wulandari menyatakan definisi penalaran matematis dalam Math Glossary sebagai berikut, Mathematical reasoning: thinking through math problems logically in order to arrive at solutions. It involves being able to identify what is important and unimportant in solving a problem and to explain or justify a solution (Wulandari 2011, 12-13). Pernyataan tersebut dapat diartikan bahwa penalaran matematis adalah berpikir mengenai permasalahan-permasalahan matematika secara logis untuk memperoleh penyelesaian dan bahwa penalaran matematis mensyaratkan kemampuan untuk memilah apa yang penting dan tidak penting dalam menyelesaikan sebuah permasalahan dan untuk menjelaskan atau memberikan alasan atas sebuah penyelesaian. Berdasarkan definisi yang tercantum pada Math Glossary tersebut, dapat diketahui bahwa terdapat dua hal yang harus dimiliki siswa dalam melakukan penalaran matematis yaitu kemampuan menjalankan prosedural penyelesaian masalah secara matematis dan kemampuan menjelaskan atau memberikan alasan atas penyelesaian yang dilakukan.

Kemampuan penalaran matematika siswa yang rendah kemungkinan disebabkan oleh faktor yang sangat dominan yaitu kecenderungan pembelajaran berpusat pada guru dan kurangnya pemahaman siswa terhadap konsep-konsep yang diberikan. Kurangnya rasa tanggungjawab dalam diri siswa sehingga mengakibatkan siswa malas dalam memecahkan masalah dan mengerjakan soal. Siswa dalam proses pembelajaran bersikap pasif menerima apa yang disampaikan oleh guru dan menyatakan kembali pengetahuannya dalam bentuk penyelesaian soal yang sifatnya rutin. Disamping itu, soal yang diberikan oleh guru cenderung memiliki penyelesaian mirip dengan contoh yang diberikan. Hal ini mengakibatkan siswa kurang melatih daya nalarnya, siswa hanya mengikuti langkah-langkah penyelesaian yang terdapat dalam contoh soal. Proses pembelajaran seperti inilah yang sering disebut dengan teacher centered.

Suasana belajar dikelas ditentukan oleh guru sesuai dengan kompetensinya. Pengaturan suasana belajar di sekolah sedemikian rupa sehingga setiap siswa mendapat pelayanan menurut kebutuhannya dan mencapai hasil pendidikan yang maksimal secara efektif dan efisien, dalam pembelajaran matematika di sekolah, guru hendaknya memilih dan menggunakan strategi, pendekatan, metode dan teknik yang banyak melibatkan siswa aktif dalam belajar, baik secara mental, fisik maupun sosial (Arikunto 2014, 3). Pemilihan model yang tepat dan sesuai dengan karakteristik siswa di kelas akan membantu siswa dalam menerima pelajaran yang diberikan dan mengaplikasikannya dalam situasi di kehidupan sehari-hari. Berdasarkan uraian tersebut, maka perlu dilakukan suatu perubahan pembelajaran matematika agar pembelajaran tersebut terasa bermakna, dengan harapan kemampuan penalaran matematis siswa dapat meningkat.

Salah satu alternatif model pembelajaran yang relevan dalam meningkatkan kemampuan penalaran matematis siswa adalah model Pembelajaran berbasis masalah (problem based learning). Pembelajaran berbasis masalah adalah suatu pembelajaran yang menggunakan masalah dunia nyata sebagai suatu konteks bagi peserta didik untuk belajar tentang cara berpikir kritis dan keterampilan pemecahan masalah serta untuk memperoleh pengetahuan dan konsep yang esensial dari materi pembelajaran (Nurhasanah 2009, 12)

Model pembelajaran berbasis masalah (problem based learning) memiliki keunggulan yaitu dalam pembelajarannya melatih siswa untuk bisa berpikir logis dan terampil berpikir rasional dalam memecahkan suatu masalah. Menurut (Sumarji 2009, 130): Karakteristik dalam pembelajaran berbasis masalah yaitu: (1) pembelajaran bersifat student centered, (2) pembelajaran pada kelompok-kelompok kecil, (3) guru berperan sebagai fasilitator dan moderator, (4) masalah menjadi fokus, (5) informasi-informasi baru diperoleh dari belajar 


\section{Vol. 1 No. 4 Oktober 2021 e-ISSN : 2774-6283 | p-ISSN : 2775-0019}

mandiri (self directed learning). Keunggulan pembelajaran berbasis masalah yaitu pembelajaran berpusat pada siswa dan guru berperan sebagai fasilitator. Langkah-langkah pembelajaran berbasis masalah yaitu: tahap pertama orientasi siswa pada masalah, tahap kedua mengorientasi siswa untuk belajar, tahap ketiga membimbing penyelidikan individu dan kelompok, tahap keempat mengembangkan dan menyajikan hasil karya, dan tahap yang terakhir adalah menganalisis dan mengevaluasi proses pemecahan masalah (Bakri 2009).

Peneliti memilih materi peluang dalam menerapkan model pembelajaran berbasis masalah. Materi ini cukup kompleks sehingga memerlukan daya nalar dalam menyelesaikan masalah-masalah yang berorientasi pada masalah-masalah kontekstual, misalnya dalam bidang olahraga untuk mengetahui banyaknya kemungkinan gol dalam setiap pertandingan sepak bola, dalam bidang ekonomi digunakan pada perusahaan asuransi, dalam bidang psikologi yaitu menggunakan frekuensi harapan dalam memperkirakan banyak siswa yang lulus ujian dan diterima di perguruan tinggi, dan bidang-bidang lainnya. Dengan demikian diperlukan peran aktif siswa dalam proses belajar mengajar dan keterampilan pemrosesan informasi yang mendalam, sehingga cocok untuk diajarkan dengan menggunakan model pembelajaran berbasis masalah.

Berdasarkan permasalahan di atas, rumusan masalah adalah "bagaimana upaya meningkatkan kemampuan penalaran matematis siswa kelas XI TKRO-A SMK Negeri 4 Jakarta melalui penerapan Pembelajaran Berbasis Masalah?"

\section{METODE PENELITIAN}

Penelitian ini dilaksanakan di SMK Negeri 4 Jakarta yang berlokasi di Jalan Rorotan VI Cilincing Jakarta Utara. Sekolah tersebut memiliki 41 (empat puluh satu) rombongan belajar. Penelitian dilaksanakan pada siswa kelas XI TKRO-A yang terdiri dari 34 siswa. Pelaksanaan penelitian ini bersifat kolaboratif, yakni adanya kerjasama antara peneliti dengan teman sejawat guru matematika lain. Peneliti bekerjasama dengan seorang teman sejawat yang mengampu mata pelajaran matematika selama pelaksanaan penelitian ini.

Waktu yang digunakan dalam penelitian ini adalah semester ganjil pada tahun pelajaran 2019/2020. Hal ini dikarenakan materi pelajaran matematika yang terkait dengan penelitian ini diajarkan pada semester ini. Pelaksanaan penelitian ini dimulai pada minggu ke-3 bulan September sampai minggu ke-2 bulan Oktober tahun 2019.

Subjek penelitian ini adalah enam orang siswa dari kelas XI TKRO-A SMKN 4 Jakarta tahun pembelajaran 2019/2020. Enam orang tersebut terdiri dari dua orang siswa dari kelompok atas, dua orang siswa dari kelompok tengah, dan dua orang siswa dari kelompok bawah. Yang dipilih berdasarkan pertimbangan rata-rata nilai penalaran matematis siswa setelah diberikan tes pada awal penelitian.

Metode yang dipilih dalam penelitian ini adalah Penelitian Tindakan Kelas (PTK) atau Classroom Action Research. Penelitian tindakan kelas dilakukan berdasarkan masalah yang terdapat pada suatu kelas untuk mencari solusi guna mencapai tujuan pembelajaran karena masalah yang diangkat merupakan masalah yang dihadapi guru di kelas dan diperlukan tindakan tertentu untuk memperbaiki proses belajar mengajar di kelas sehingga hasil belajar siswa meningkat sesuai dengan yang diharapkan. Prosedur langkah penelitian ini mengikuti model Kemmis dan Mc. Taggart. Tiap siklus terdiri dari empat tahap, yaitu: (1) perencanaan (plan), (2) tindakan (action), (3) pengamatan (observation), dan (4) refleksi (reflection).

Penelitian ini dirancang untuk tiga siklus tindakan. Setiap siklus terdiri dari proses perencanaan, pelaksanaan, observasi, dan refleksi. Jika dalam suatu siklus belum diperoleh hasil yang maksimal, maka dilanjutkan tahapan pada siklus selanjutnya.

Sumber data dalam penelitian ini adalah siswa kelas XI TKRO-A SMK Negeri 4 Jakarta tahun pelajaran 2019/2020. Data dalam penelitian ini meliputi data hasil pengamatan diperoleh dari kolaborator dan guru selaku peneliti dan data hasil tes kemampuan penalaran matematis. Lembar Observasi digunakan untuk mengumpulkan data melalui pengamatan pelaksanaan 
Vol. 1 No. 4 Oktober 2021 e-ISSN : 2774-6283 | p-ISSN : 2775-0019

pembelajaran berbasis masalah. Kemampuan penalaran matematis diukur dengan tes yang telah divalidasi oleh ahli sebelum digunakan.

Pelaksanaan observasi pada saat pembelajaran berlangsung dimulai dari siklus I sampai dengan siklus III. Observasi yang dilaksanakan didasarkan pada indikator-indikator dalam lembar observasi pelaksanaan pembelajaran yang telah ditetapkan. Sedangkan kemampuan penalaran matematis, diukur melalui indikator: (1) Memperkirakan jawaban dan proses solusi; (2) Menggunakan pola dan hubungan untuk menganalisis situasi matematika; (3) Menarik kesimpulan logis dari pernyataan; dan (4) Memberikan penjelasan dengan menggunakan model, fakta dan hubungan dalam menyelesaikan soal.

Teknik analisis yang digunakan adalah analisis deskriptif dan analisis deskriptif komparatif yakni membandingkan rata-rata atau persentase kemampuan penalaran matematis dari pembelajaran berbasis masalah dari setiap siklus.

Adapun indikator atau tolok ukur keberhasilan tindakan adalah apabila peningkatan kemampuan penalaran matematis siswa hingga mencapai kualifikasi cukup $(40 \leq P<60)$ dan nilai rata-rata siswa minimal memiliki kualifikasi minimal Baik $(60 \leq \bar{X}<80)$.

\section{HASIL DAN PEMBAHASAN}

Secara umum hasil analisis menunjukkan adanya peningkatan kemampuan penalaran matematis siswa setelah dilaksanakan pembelajaran melalui penerapan pembelajaran berbasis masalah. Peningkatan nilai rata-rata kemampuan penalaran matematis berdasarkan siklus I, II, dan III dari subjek penelitian SP1, SP2, SP3, SP4, SP5, dan SP6 disajikan pada Tabel 1.

Tabel 1. Nilai Kemampuan Penalaran Matematis Siklus I, II, dan III

\begin{tabular}{lcccc}
\hline Subject & Pra-siklus & Siklus I & Siklus II & Siklus III \\
\hline SP1 & 68,75 & 81,25 & 93,75 & 93,75 \\
SP2 & 50,00 & 87,50 & 75,00 & 87,50 \\
SP3 & 43,75 & 43,75 & 75,00 & 93,75 \\
SP4 & 37,50 & 56,25 & 75,00 & 81,25 \\
SP5 & 25,00 & 81,25 & 75,00 & 75,00 \\
SP6 & 6,25 & 43,75 & 68,75 & 75,00 \\
\hline Rata-rata & $\mathbf{3 8 , 5 4}$ & $\mathbf{6 5 , 6 3}$ & $\mathbf{7 7 , 0 8}$ & $\mathbf{8 4 , 3 8}$ \\
\hline
\end{tabular}

Secara grafis nilai rata-rata kemampuan penalaran matematis berdasarkan pra-siklus, siklus I, II, dan III, disajikan pada Gambar 1.

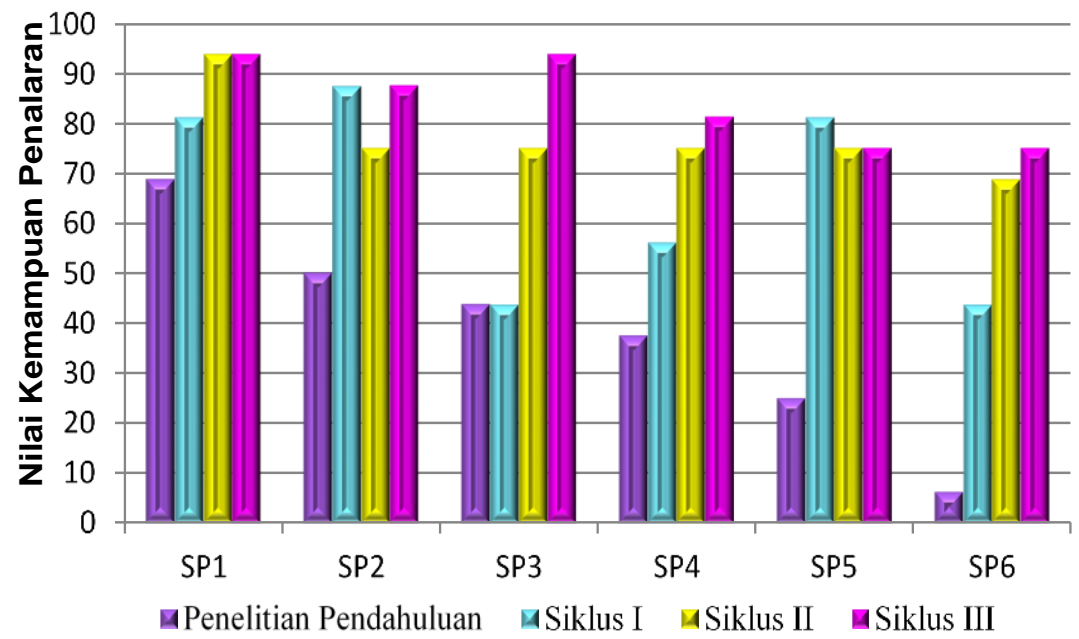

Gambar 1.Diagram Nilai Kemampuan Penalaran Matematis Subjek Penelitian 
Vol. 1 No. 4 Oktober 2021 e-ISSN : 2774-6283 | p-ISSN : 2775-0019

Berdasarkan hasil analisis pada Tabel 1 dan Gambar 1, menunjukkan bahwa masingmasing subjek penelitian mengalami peningkatan kemampuan penalaran matematis yaitu untuk SP1, SP3, SP4 dan SP6. Sedangkan SP2 dan SP5, mengalami penurunan nilai kemampuan penalaran matematis akhir siklus II, tetapi penurunan ini masih berada dalam indikator keberhasilan tindakan dalam penelitian ini yaitu hingga mencapai kualifikasi cukup. Sementara nilai tes kemampuan penaran SP2 dan SP5 pada siklus II yaitu 75,00 termasuk dalam kualifikasi baik. Secara visual peningkatan rata-rata kemampuan penalaran matematis dari 34 siswa berdasarkan tindakan pada setiap siklus disajikan pada Gambar 2.

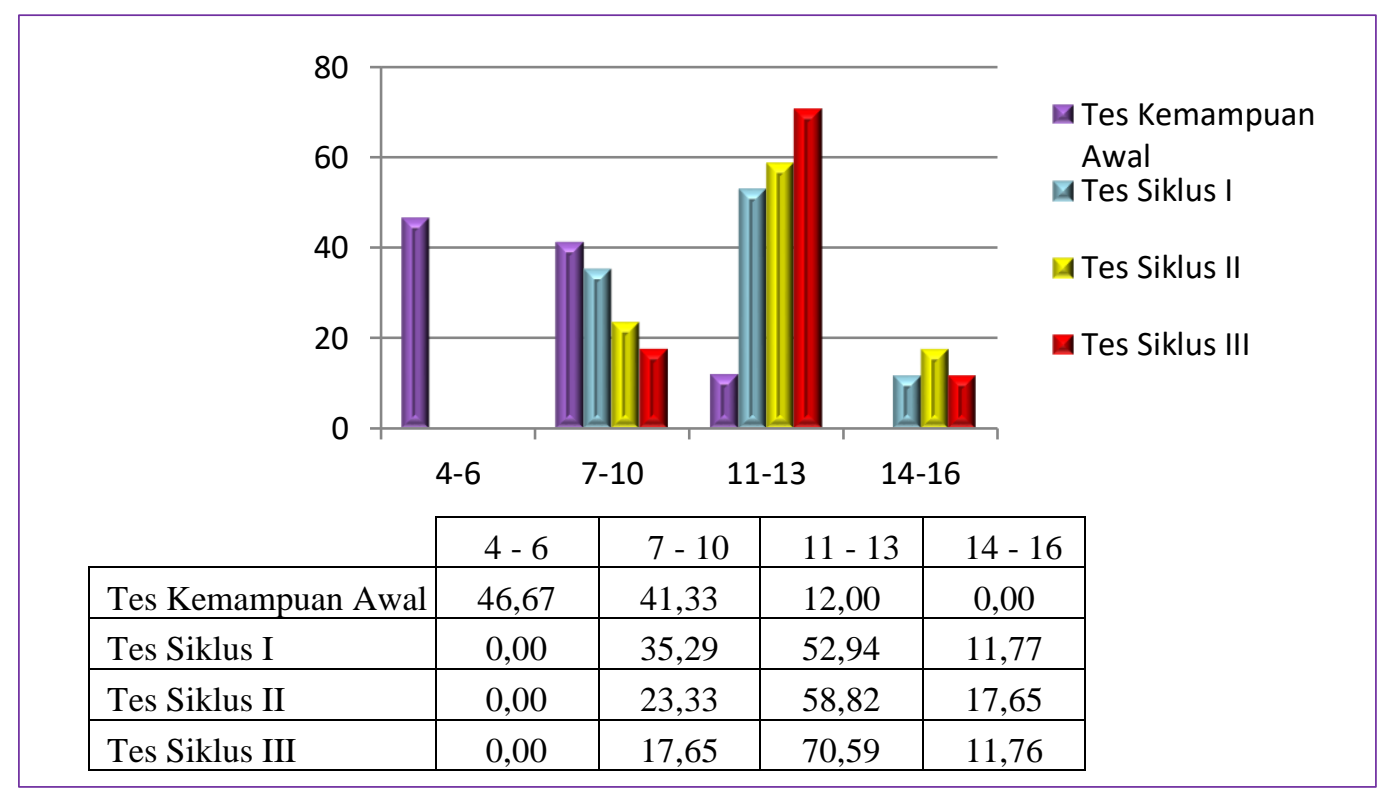

Gambar 2. Diagram Peningkatan Persentase Nilai Kemampuan Penalaran Matematis Siswa Menurut Siklus

Hasil analisis pada Gambar 2, menunjukkan bahwa persentase kemampuan penalaran matematis dari 34 siswa pada kemampuan awal, siklus I, II, dan III dalam rentang skor 4-6 (2538) sebesar 0\%. Persentase siswa yang mencapai rentang skor 7-10 (44-63), mengalami penurunan, yaitu pada siklus I (35,29\%), siklus II $(23,33 \%)$, dan siklus III $(17,65 \%)$, capaian pada setiap siklus masih di bawah rata-rata kemampuan awal. Persentase siswa mencapai rentang skor 11-13 (69-81) mencapai kenaikan, yaitu pada siklus I (52,94\%), siklus II $(58,82 \%)$, dan siklus III $(70,59 \%)$, dimana capaian ini sudah berada di atas rata-rata kemampuan awal Persentase siswa yang mencapai rentang skor 14-16 (88-100), mengalami fluktuasi turun-naik, yaitu pada siklus I (11,77\%), siklus II $(17,65 \%)$, dan siklus III $(11,76 \%)$, capaian pada setiap siklus masih di atas rata-rata kemampuan awal. Dengan demikian, temuan penelitian menunjukkan bahwa untuk persentase rentang skor (7-10) menurun, (11-13) meningkat sesuai siklus, dan skor (14-16) cenderung berfluktuasi meningkat kemudian menurun pada siklus III.

Tabel 3. Kemampuan Penalaran Matematis Siswa dari Tes Kemampuan Awal sampai Tes Akhir Siklus III (n=34)

\begin{tabular}{lcccc}
\hline \multirow{2}{*}{ Kriteria } & \multicolumn{4}{c}{ Jumlah siswa } \\
\cline { 2 - 5 } & $\begin{array}{c}\text { Tes } \\
\text { Kemampuan } \\
\text { Awal }\end{array}$ & $\begin{array}{c}\text { Tes Akhir } \\
\text { Siklus I }\end{array}$ & $\begin{array}{c}\text { Tes Akhir } \\
\text { Siklus II }\end{array}$ & $\begin{array}{c}\text { Tes Akhir } \\
\text { Siklus III }\end{array}$ \\
\hline Sangat Baik & 0 & 4 & 6 & 4 \\
Baik & 4 & 18 & 20 & 24 \\
Cukup & 14 & 12 & 8 & 6 \\
Kurang & 16 & 0 & 0 & 0 \\
\hline
\end{tabular}


Secara umum temuan penelitian menunjukkan bahwa rata-rata nilai tes kemampuan penalaran matematis dari 34 siswa mengalami peningkatan, yaitu pada siklus II, rata-rata nilai kemampuan penalaran matematis siswa meningkat menjadi 72,24 . Sementara pada siklus III, rata-rata nilai kemampuan penalaran matematis siswa meningkat sebesar 1,84\% menjadi 74,08. Nilai tes penalaran matematis siswa pada siklus III juga menunjukan bahwa siswa yang mencapai nilai KKM (75) meningkat dibandingkan dengan pencapaian pada siklus II, yaitu meningkat menjadi 28 orang siswa atau 82,35\% dari keseluruhan siswa.

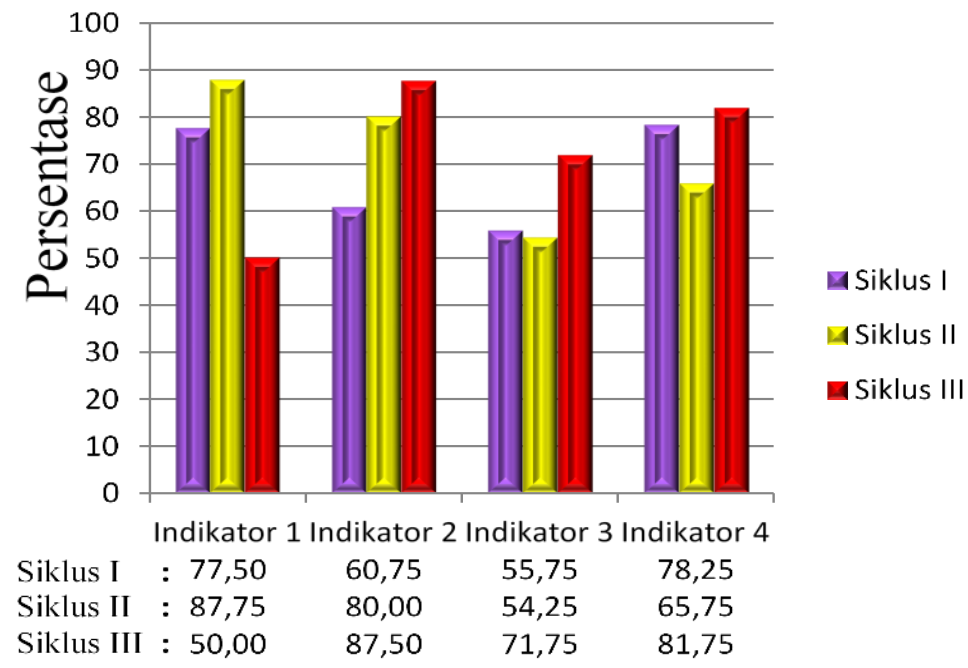

\section{Gambar 3. Diagram Persentase Rata-RataNilai Kemampuan Penalaran Matematis Siswa per-Indikator Siklus I, II, dan III}

Hasil analisis sebagaimana disajikan pada Gambar 3, menunjukkan bahwa rata-rata kemampuan penalaran matematis seluruh siswa mengalami peningkatan pada indikator ke-2 (menggunakan pola dan hubungan untuk menganalisis situasi matematika), ke-3 (menarik kesimpulan logis dari pernyataan) dan ke-4 (memberikan penjelasan dengan menggunakan model, fakta dan hubungan dalam menyelesaikan soal). Sedangkan pada indikator ke-1 (memperkirakan jawaban dan proses solusi) rata-rata kemampuan penalaran matematis siswa mengalami penurunan. Rata-rata kemampuan penalaran matematis siswa mencapai nilai paling tinggi pada indikator ke-2, yaitu sebesar $87,50 \%$ atau termasuk dalam kategori sangat baik.

Temuan kemampuan penalaran matematis menurut indikator 1, yaitu memperkirakan jawaban dan proses solusi, disajikan pada cuplikan jawaban SP1 dan SP3, pada Gambar 4. Berdasarkan temuan gambar 4, indikator penalaran kemampuan memperkirakan jawaban dan proses solusi, menunjukkan SP1 berhasil menjawab sempurna, yaitu sudah dapat memperkirakan jawaban dan proses solusi dengan tepat. SP2 dan SP3 dapat menjawab dengan benar namun masih ada sedikit yang tidak sesuai, sementara SP4, SP5 dan SP6 belum bisa menjawab dengan tepat, terlihat adanya proses solusi namun hanya sedikit perkiraan jawaban yang benar. Dengan demikian kemampuan pada indikator memperkirakan jawaban dan proses solusi pada siklus III mengalami penurunan dari siklus I dan II. Hasil analisis terhadap materi, mengasumsikan bahwa kecenderungan penurunan kemampuan pada indikator ini dikarenakan materi yang semakin sulit dan semakin kompleks. 
1. Kotak berisi koin Rp209 4 koin Rp590, dan 6 koin Rp1.000 6 koin diambil tanpa pengembalian, dtmen setiap koin memiliki peluang terpilih yang sama. Bagaimana cara memperkirakan peluang 6 koin yang terambil memiliki jumlah minimal $\mathrm{Rp} 5.000$ ? $\mathrm{N}(\mathrm{S})=924$

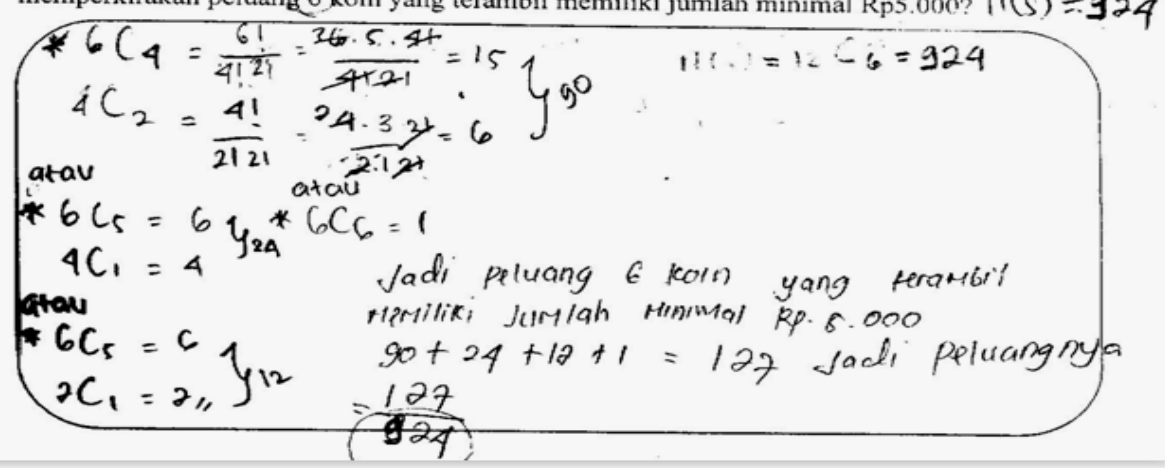

\section{SP1}

1. Kotak berisi 2 koin Rp200, 4 koin Rp500, dan 6 koin Rp1.000. 6 koin diambil tanpa pengembalian, dimana setiap koin memiliki peluang terpilih yang sama. Bagaimana cara memperkirakan peluang 6 koin yang terambil memiliki jumlah minimal Rp5.000?

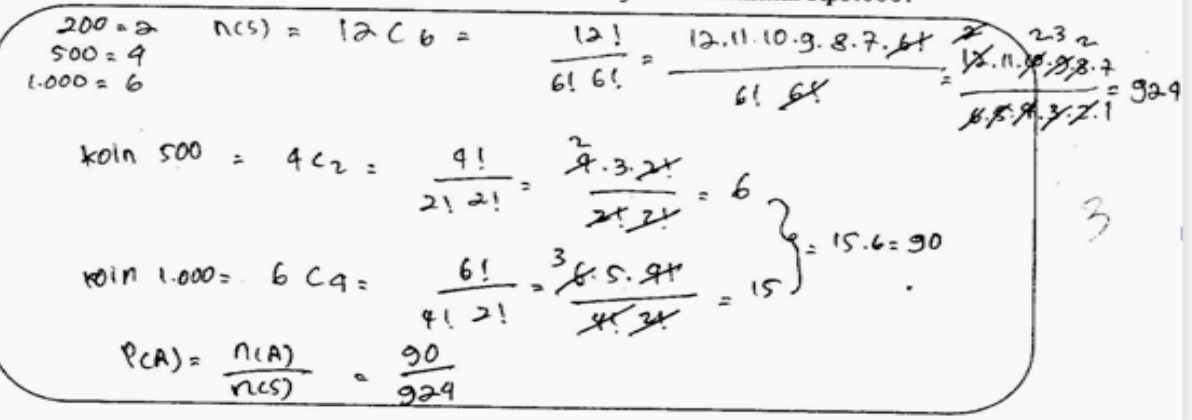

\section{SP3}

\section{Gambar 4. Perbedaan Jawaban SP1 dan SP3 Siklus III Indikator 1}

Temuan kemampuan penalaran matematis indikator 2, yaitu, kemampuan menggunakan pola dan hubungan untuk menganalisis situasi matematis, disajikan pada cuplikan jawaban Gambar 5. Berdasarkan gambar 4, Soal kedua bagian a) dan b) merupakan soal yang dapat diselesaikan dengan konsep peluang kejadian bersyarat. Tujuan diberikannya pertanyaan ini adalah untuk mengetahui perkembangan kemampuan siswa dalam menyelesaikan soal mengaitkan dengan konsep peluang.

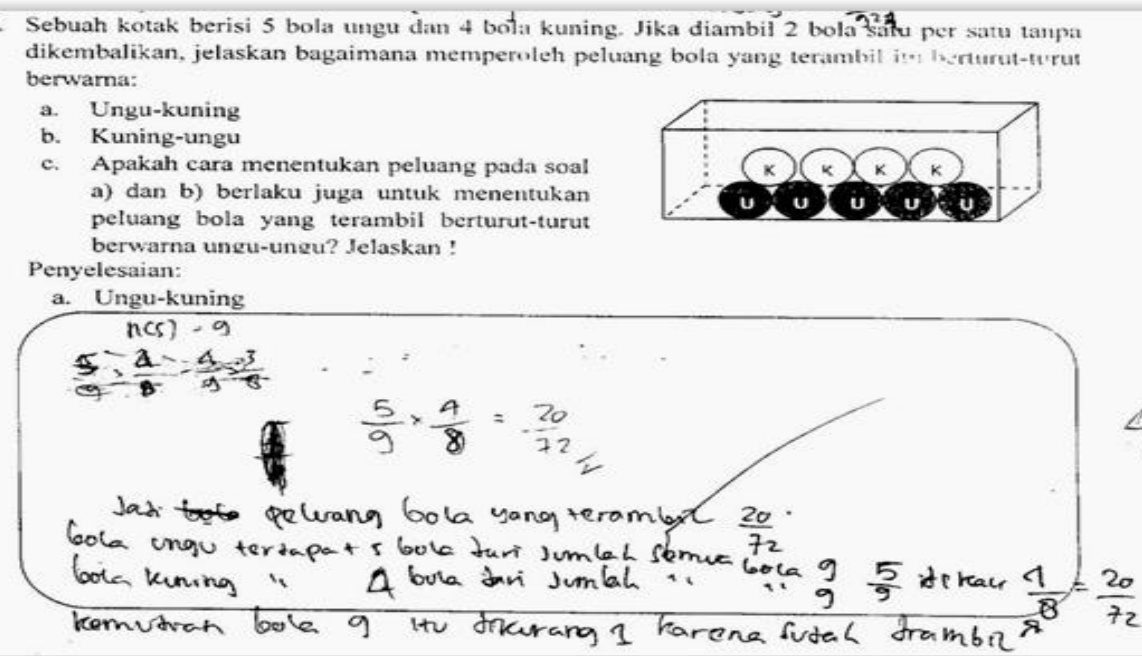




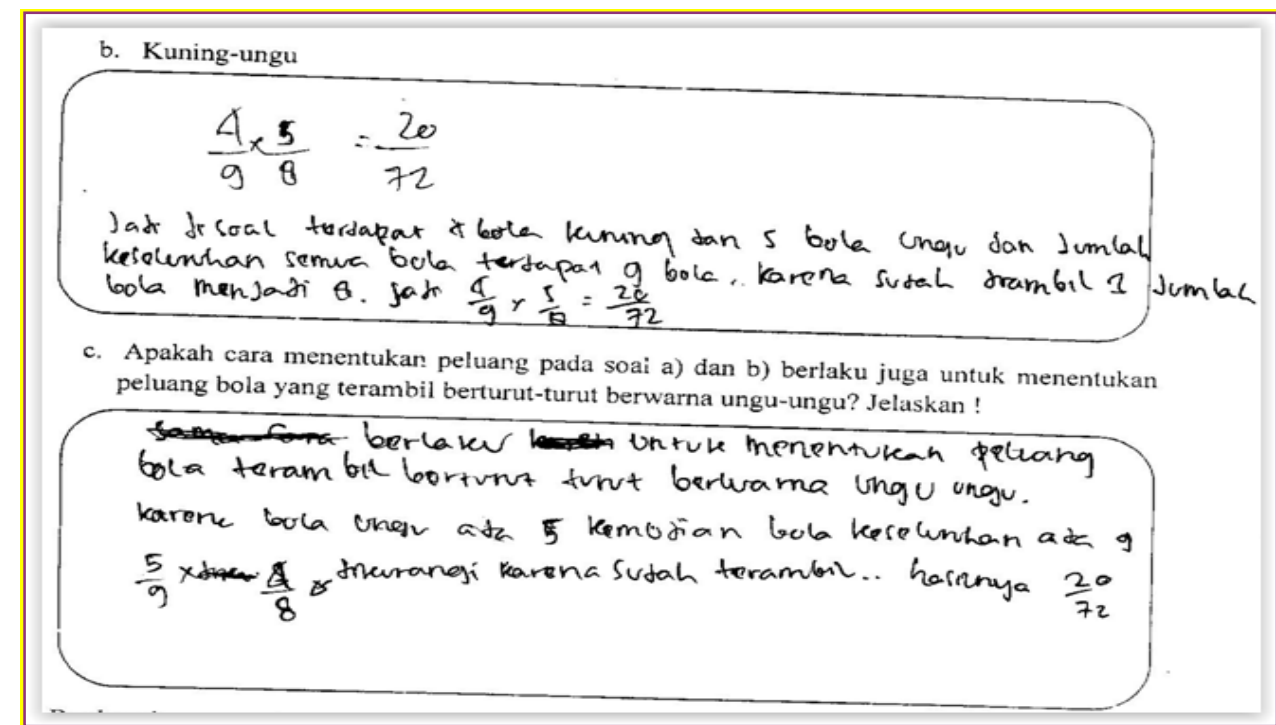

\section{Gambar 5. Jawaban siswa pada Indikator 2}

Pertanyaan c) menuntut siswa harus dapat menyelesaikan pertanyaan dengan menggunakan pola dan hubungan dari jawaban soal bagian a) dan b). Seluruh subjek penelitian dapat menjawab pertanyaan ini dengan benar.. Hal ini berarti bahwa secara keseluruhan baik siswa maupun SP dapat mengembangkan kemampuan menggunakan pola dan hubungan untuk menganalisis situasi matematis secara optimal.

Temuan kemampuan penalaran matematis indikator 3, yaitu, kemampuan menarik kesimpulan logis, disajikan pada cuplikan jawaban Gambar 6. Temuan pada Gambar 6 menujukkan contoh jawaban seorang siswa pada indikator kemampuan menarik kesimpulan logis, yang disajikan dalam bentuk kontekstual masalah nyata dalam kehidupan sehari-hari. Temuan penelitian pada indikator 3, menunjukkan bahwa SP2 dan SP3 yang sudah dapat menarik kesimpulan logis. Sedangkan SP1, SP4 dan SP5 dapat menarik kesimpulan logis dari soal yang diberikan namun masih ada sedikit yang tidak sesuai. Sementara SP6 hanya mengetahui prosesnya, belum dapat menarik kesimpulan logis dari suatu pernyataan. Secara keseluruhan siswa sudah dapat meningkatkan kemampuan penalaran matematis pada indikator menarik kesimpulan logis.

3. Berdasarkan pengalaman yang lalu, seorang pialang saham yakin bahwa dalam keadaan ekonomi yang sekarang langganan akan menanam modalnya dalam obligasi bebas pajak dengan peluang 0,6 , dalam dana bersama (Mutual Funds) dengan peluang 0.3 dan dalan keduanya dengan peluang 0,15 . Pada keadaan sekarang, carilah:

a. Peluang seorang langganan akan menanam modainya dalam obligasi bebas pajak atau dana bersama.

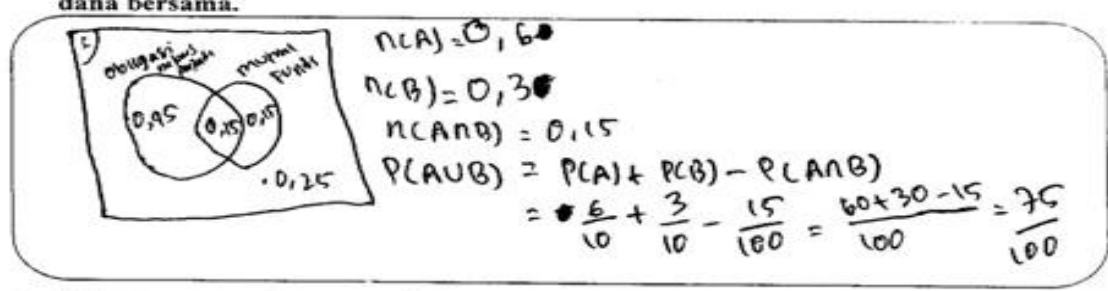

b. Peluang seorang langganan akan menanam modalnya tidak dalam salah satupun dar keduanya, buatlah kesimpulan dari proses mencari peiuang tersebut!

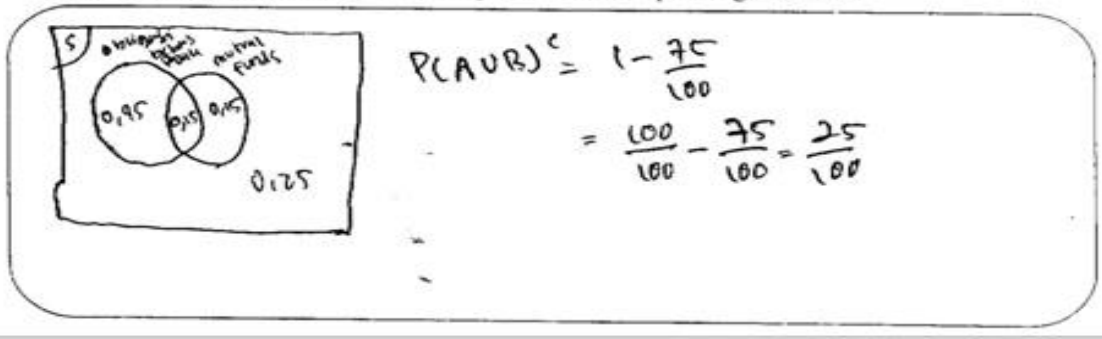

Gambar 6.Jawaban Siswa pada Indikator 3 
Temuan kemampuan penalaran matematis indikator 4, yaitu, kemampuan memberikan penjelasan dengan menggunakan model, fakta dan hubungan dalam menyelesaikan soal, disajikan pada cuplikan jawaban Gambar 7.

Temuan penelitian pada Gambar 7, indikator 4, menujukkan bahwa SP1, SP3, SP4 dan SP6 dapat menjawab soal dengan benar, sementara SP2 dan SP5 mampu memberikan penjelasan dengan menggunakan model, fakta dan hubungan dalam menyelesaikan soal namun masih ada sedikit yang tidak sesuai. Dengan demikian, secara keseluruhan siswa dapat meningkatkan kemampuan penalaran matematis pada indikator kemampuan memberikan penjelasan dengan menggunakan model, fakta dan hubungan dalam menyelesaikan soal secara optimal

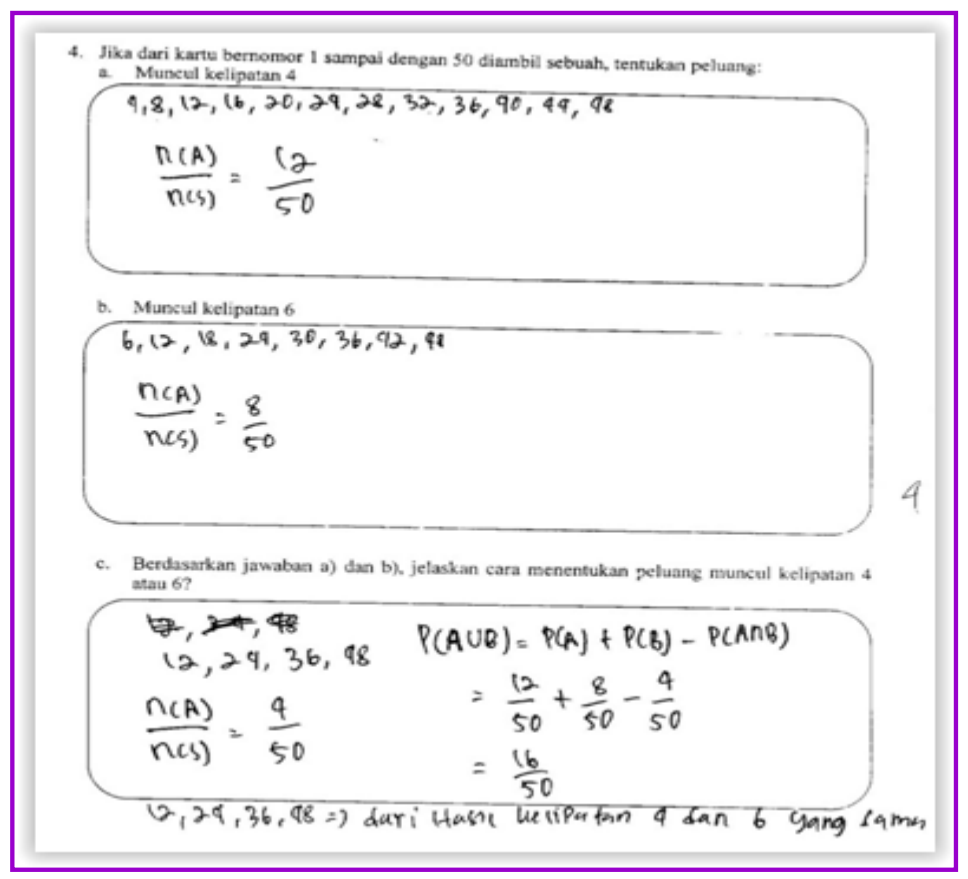

Gambar 7. Jawaban Siswa pada Indikator 4

Temuan penelitian menunjukkan bahwa pembelajaran berbasis masalah dapat meningkatkan kemampuan penalaran matematis siswa. Temuan penelitian yang relevan dengan penelitian ini antara lain penelitian yang dilakukan oleh Nadiroh (2014) dalam Penerapan Pembelajaran Kooperatif Tipe "MURDER" untuk Meningkatkan Kemampuan Penalaran Matematis Siswa Kelas X Sosial 3 SMAN 1 Martapura pada Materi Persamaan Kuadrat. Berdasarkan hasil penelitian tersebut, menunjukkan bahwa kemampuan penalaran matematis siswa dapat ditingkatkan dengan perlakuan tertentu.

\section{KESIMPULAN}

Berdasarkan hasil penelitian dan pembahasan, simpulan penelitian adalah bahwa pembelajaran matematika dengan penerapan pembelajaran berbasis masalah dapat meningkatkan kemampuan penalaran matematis siswa kelas XI TKRO-A SMK Negeri 4 Jakarta Semester Ganjil Tahun Pelajaran 2019-2020. Peningkatan kemampuan penalaran matematis meliputi indikator: (1) memperkirakan jawaban dan proses solusi; (2) menggunakan pola dan hubungan untuk menganalisis situasi, atau membuat analogi, generalisasi, dan menyusun konjektur (3) menarik kesimpulan logik; dan (4) memberikan penjelasan dengan menggunakan model, fakta, sifat, hubungan atau pola.

Berdasarkan simpulan penelitian ini, maka dengan pembelajaran matematika melalui penerapan pembelajaran berbasis masalah disarankan kepada guru mata pelajaran matematika untuk menerapkan strategi ini ke sekolah-sekolah dalam pembelajaran matematika. Waktu 
dalam kegiatan pembelajaran hendaknya diperhatikan dan dialokasikan secara optimal, tepat, dan konsisten agar pembelajaran matematika di kelas dapat berlangsung efektif.

\section{DAFTAR PUSTAKA}

Alwisol. (2009). Psikologi Kepribadian (Edisi Revisi) . Malang: UMM Press

Arikunto, Suharsimi. (2014). Pengelolaan Kelas dan Siswa. Jakarta: Raja Grafindo Persada

Bakri, Hasrul. (2009). Peningkatan Minat Belajar Praktek Menggulung Trafo Melalui Pendekatan Pembelajaran Berbasis Masalah (Problem Based Learning) Pada Siswa SMK Negeri 3 Makassar. MEDTEK Vol. 1 No. 1 ,

Lestari, N. W. R. (2008). Pengaruh Model Penilaian dan Setting Pembelajaran Kooperatif terhadap Hasil Belajar Fisika Siswa Kelas X SMA Negeri 4 Singaraja Tahun Pelajaran 2007/2008. Skripsi, Singaraja: Tidak diterbitkan

Nurhasanah, L. (2009). Meningkatkan Kompetensi Strategis (Strategic Competence) Siswa SMP melalui model PBL (Problem Based Learning). Skripsi, Bandung: FMIPA UPI Tidak diterbitkan

Sumarji. (2009). Penerapan Pembelajaran Model Problem Based Learning Untuk Meningkatkan Motivasi dan Kemampuan Pemecahan Masalah Ilmu Statistika dan Tegangan di SMK. Teknologi dan Kejuruan, Vol. 32 No. 2 : 129-140.

Wulandari, Enika. (2011). Meningkatkan Kemampuan Penalaran Matematis Siswa. Skripsi, Yogyakarta: FMIPA UNY 